\title{
Comparison of DNA Profiling between Fishes and Pork Meat using Polymerase Chain Reaction-Restriction Fragment Length Polymorphisms (PCR-RFLP) Analysis \\ (Perbandingan Profil DNA antara Ikan dan Daging Babi menggunakan Analisis Tindak Balas \\ Rantaian Polimerase-Polimorfisme Panjang Cebisan Pemotongan (PCR-RFLP))
}

\author{
SAFIYYAH Shahimi, SAHIlaH ABD. MUtAliB*, WAN SAKEENAH WAN NAZRI, \\ AMINAH ABDULLAH \& NORRAKIAH ABDULLAH SANI
}

\begin{abstract}
Genomic DNA of 13 fish ( $\mathrm{n}=13)$ species consist of four freshwater which were catfish (Clarias gariepinus), shark catfish (Pangasius larnaudii), tilapia (Oreochromis mossambicus), perch (Lates calcarifer) and nine marine species which were black pomfret (Parastromateus niger), anchovy (Stolephorus commersonii), mabong (Rastrelliger kanagurta), red snapper (Lutjanus erythropterus), herring (Chirocentrus dorab), ray fish (Himantura gerrardii), sardine (Decapterus macrosoma), mackerel (Euthynnus affinis) and tuna (Thunnus tuna) were differentiated using polymerase chain reaction-restriction fragment length polymorphism (PCR-RFLP). Seven endonucleases of AluI, BsaJI, HaeIII, HindIII, HinfI, MboI and MboII were examined for the ability to digest cyt $b$ amplicon from each species. Genomic DNA of pork (Sus scrofa domestica) were differentiated from fishes by comparing the digestion patterns produced by similar amplified region and enzymes used. In the present study, it was demonstrated that fishes and pork DNA genome were successfully differentiated using all endonucleases except for HindIII. Thus, PCR-RFLP analysis was found useful for future pork DNA detection in fish products.
\end{abstract}

Keywords: DNA profiling; fish; PCR-RFLP; pork (Sus scrofa domestica)

ABSTRAK

DNA genomik 13 spesies ikan ( $\mathrm{n}=13$ ) terdiri daripada empat ikan air tawar iaitu keli (Clarias gariepinus), patin (Pangasius larnaudii), tilapia (Oreochromis mossambicus), siakap (Lates calcarifer) dan sembilan ikan air masin iaitu bawal hitam (Parastromateus niger), ikan bilis (Stolephorus commersonii), mabong (Rastrelliger kanagurta), ikan merah (Lutjanus erythropterus), ikan parang (Chirocentrus dorab), pari (Himantura gerrardii), sardin (Decapterus macrosoma), tenggiri (Euthynnus affinis) dan tuna (Thunnus tuna) telah dibezakan menggunakan tindak balas rantaian polimerase-polimorfisme panjang cebisan pemotongan (PCR-RFLP). Tujuh endonuklease iaitu AluI, BsaJI, HaeIII, HindIII, HinfI, MboI dan MboII telah dinilai kebolehannya bagi mencernakan amplikon cyt b daripada setiap spesies. DNA genomik babi (Sus scrofa domestica) telah dibezakan daripada ikan dengan membandingkan corak pencernaan yang terhasil ke atas kawasan amplifikasi yang serupa menggunakan enzim yang digunakan. Dalam kajian ini, DNA genomik ikan dan babi telah berjaya dibezakan oleh kesemua endonuklease kecuali enzim HindIII.

Kata kunci: Babi (Sus scrofa domestica); ikan; PCR-RFLP; pemprofilan DNA

\section{INTRODUCTION}

The interests of Halal concept keep expanding over the world especially in Muslim majority countries. One of the common issues in Halal industry is Halal meat authentication. Authenticity, such as adulteration, improper description of the products and origin designation (Monin 1998 ) is an important aspect in meat quality evaluation. Due to health concern and awareness of fish meat nutrition, there are increasing trends in fish consumption nowadays. Fish consumption may lead to allergy in some group of people such as diet control for women in confinement, other than religious constriction. Thus, meat comparison between species is important as a fresh whole-fish can be easily identified by consumers, but identification has been a big issue after its transformation into processed products. Fish-based products like fish ball, fish fillet and ready- to-eat canned product has been widely commercialized nowadays. There are potential adulterations of fish products such as surimi were added with pork gelatin to improve its texture and juiciness of the product. Both fish and pork gelatin are impossible to be differentiated by naked eyes especially when the product had undergone heat treatment (Koh et al. 1998).

Polymerase Chain Reaction (PCR) technique was reported very precise to detect meat adulteration in meat species identification for routine analysis (Matsunaga et al. 2001). The use of seven restriction enzyme endonucleases in this PCR-Restriction Fragment Length Polymorphism (PCR-RFLP) analysis were expected to generate a unique genetic profiling for each meat species, based on the size and number of DNA fragments being produced after the enzymatic digestion of $c y t \mathrm{~b}$ amplicons. The PCR-RFLP 
analysis is useful for the detection of inter-species as well as intra-species genetic variations. Thus, the objective of this study was to compare the fish and pork DNA based on enzyme restriction patterns produced by the PCR-RFLP analysis.

\section{MATERIALS AND METHODS}

\section{SAMPLE PREPARATION}

Fresh samples of 13 fish species were chosen consist of freshwater and marine types. Four freshwater species namely catfish (Clarias gariepinus), shark catfish (Pangasius larnaudii), tilapia (Oreochromis mossambicus), perch (Lates calcarifer) and ten marine species which were black pomfret (Parastromateus niger), anchovy (Stolephorus commersonii), mabong (Rastrelliger kanagurta), red snapper (Lutjanus erythropterus), herring (Chirocentrus dorab), ray fish (Himantura gerrardii), sardine (Decapterus macrosoma), mackerel (Euthynnus affinis) and tuna (Thunnus tuna) were purchased from Carrefour supermarket, Alamanda, Putrajaya from March to December 2010. While, pork (Sus scrofa domestica) was purchased from a wet market in Seksyen 13, Petaling Jaya, Selangor in March 2009. All samples were kept frozen at $-20^{\circ} \mathrm{C}$ before DNA extraction process to prevent enzymatic degradation.

\section{EXTRACTION OF TOTAL DNA}

DNA of fish meats and pork samples were extracted using DNA Extraction Kit (DNeasy Blood and Tissue Kit Qiagen, USA). A total of $25 \mathrm{mg}$ meat from each sample was minced and placed in a sterile $1.5 \mathrm{~mL}$ microcentrifuge. The extracted DNA were measured using ultra-violet (UV) spectrophotometer (Maestro-Nano, MY) at 260/280 nm wavelength (Ong et al. 2007).

\section{OLIGONUCLEOTIDE PRIMERS}

The primers used were targeting the universal mitochondrial $c y t$ b namely CYT b1: 5 '-CCATCCAACATCTCA GCATGATGAAA-3' (forward) and CYT b2: 5'- GCCCCTCAGAATG ATATTTGTCCTCA-3' (reverse) as described by Kocher et al. (1989). The primers were supplied by First Base Laboratories (Selangor, MY).

\section{PCR AMPLIFICATION}

PCR was done using PCR thermal cycler (Eppendorf, GY) to amplify mitochondrial $c y t \mathrm{~b}$ region. PCR amplification was performed in $50 \mu \mathrm{L}$ total reaction mixture consists of genomic DNA in $10 \mu \mathrm{L}$ water (25-30 ng), $25 \mu \mathrm{L}$ of PCR Dream Taq ${ }^{\circledR}$ master mix, $1 \mu \mathrm{L}$ of forward primer $(100 \mu \mathrm{M})$, $1 \mu \mathrm{L}$ of reverse primer $(100 \mu \mathrm{M})$ and $13 \mu \mathrm{L}$ nuclease-free water. Positive control (pork DNA) and negative control were included in each PCR cycle.

The PCR step-cycle program used as described by Kocher et al. (1989): Early denaturation at $94^{\circ} \mathrm{C}$ for 2 min, followed by 35 cycle of denaturation at $94^{\circ} \mathrm{C}$ for 15 $\mathrm{s}$, annealing at $50^{\circ} \mathrm{C}$ for $1 \mathrm{~min}$ and elongation at $72^{\circ} \mathrm{C}$ for 1 min. The final extension was at $72^{\circ} \mathrm{C}$ for 2 min to produce a complete PCR product. The amplification products were analyzed using $2 \%(\mathrm{w} / \mathrm{v})$ agarose gel in $1 \mathrm{X}$ TAE buffer at $100 \mathrm{~V}$ for $40 \mathrm{~min}$. Nucleic acid staining was done using ethidium bromide solution. A 100 bp DNA ladder (Vivantis, MY) was used as size marker.

\section{ENZYMATIC DIGESTION OF AMPLIFIED DNA}

A total of $10 \mu \mathrm{L}$ amplicon, $10 \mu \mathrm{L}$ enzyme reaction buffer (10X), $1 \mu \mathrm{L}$ restriction endonuclease (RE) $(10 \mathrm{u} / \mu \mathrm{L})$ (Vivantis, MY) and $9 \mu \mathrm{L}$ nuclease-free water were mixed to give a final volume of $30 \mu \mathrm{L}$ in each reaction. The mixture was then incubated at $37^{\circ} \mathrm{C}$ to $55^{\circ} \mathrm{C}$, depending on the type of enzyme used. The incubation period was set for $3 \mathrm{~h}$. This step was applied to all samples using restriction enzyme AluI, BsaJI, HaeIII, HindIII, Hinf I, MboI and MboII.

The fragments obtained after digestion of amplification products by restriction enzyme were analysed using agarose gel electrophoresis $3 \%(\mathrm{w} / \mathrm{v})$ to estimate the size of each fragment produced. Gel was stained using ethidium bromide $(\mathrm{EtBr})$ before viewed under a UV-transluminator imager (Alpha Innotech, USA). Sizes of the amplicons were estimated from the DNA marker. A table based on the size (bp) of bands appeared on the gel was tabulated to differentiate between samples (Table 1).

\section{RESULTS}

\section{PCR AMPLIFICATION USING MITOCHONDRIAL CYT B OLIGOPRIMERS}

Genomic DNA 13 species of raw fishes and pork (Sus scrofa domestica) were successfully extracted using extraction kit (DNeasy® Blood and Tissue Kit Qiagen, USA). PCR assay was performed using the same universal mitochondrial CYTb primers (Kocher et al. 1989) on both fish and pork samples. Gel electrophoresis on $2 \%(w / v)$ agarose for fish amplicon produced 359 bp in size except for tilapia (Oreochromis mossambicus) and anchovy (Stolephorus commersonii) (Figure 1). None amplicons were detected for the said fish samples though the experiment was repeated three times using the same universal primers (Primers CYTb1/CYTb2). While, amplification of pork DNA using the same universal primer (CYTb1/CYTb2) produced similar amplicon size of $359 \mathrm{bp}$ (Figure 2).

\section{PCR-RFLP ANALYSIS}

The patterns produced by each type of enzyme were recorded to tabulate a unique DNA profiles for each fish and pork, after enzymatic digestion by seven restriction endonucleases. Molecular weights of DNA fragments for 12 samples (fishes and pork) produced after enzymatic digestion using the seven restriction enzymes were listed in Table 1. Every restriction pattern produced by amplicon 
TABLE 1. $C y t$ b DNA amplicon sizes of samples after digestion by restriction endonucleases

\begin{tabular}{|c|c|c|c|c|c|c|c|}
\hline \multirow[t]{2}{*}{ Types of samples } & \multicolumn{7}{|c|}{ Size of DNA Band (bp) } \\
\hline & AluI & BsaJI & HaeIII & HindIII & $\operatorname{HinfI}$ & MboI & MboII \\
\hline \multirow{2}{*}{$\begin{array}{l}\text { Pig } \\
\text { (Sus scrofa domesticus) }\end{array}$} & $*(1)$ & $*(2)$ & $*(3)$ & $*(4)$ & $*(4)$ & $*(1)$ & $*(4)$ \\
\hline & 115,244 & 131,228 & 125,134 & 359 & 359 & 115,244 & 359 \\
\hline \multirow{2}{*}{$\begin{array}{l}\text { Catfish } \\
\text { (Clarias gariepinus) }\end{array}$} & $*(5)$ & $*(6)$ & $*(7)$ & $*(4)$ & $*(8)$ & $*(4)$ & $*(8)$ \\
\hline & $170,130,59$ & 225,134 & 229,130 & 359 & 200,159 & 359 & 200,159 \\
\hline \multirow{2}{*}{$\begin{array}{l}\text { Shark catfish } \\
\text { (Pangasius larnaudii) }\end{array}$} & $*(5)$ & $*(4)$ & $*(4)$ & $*(4)$ & $*(8)$ & $*(9)$ & $*(4)$ \\
\hline & $170,130,59$ & 359 & 359 & 359 & 200,159 & 300 & 359 \\
\hline $\begin{array}{l}\text { Tilapia } \\
\text { (Oreochromis mossambicus) }\end{array}$ & - & - & - & - & - & - & - \\
\hline \multirow{2}{*}{$\begin{array}{l}\text { Perch } \\
\text { (Lates calcarifer) }\end{array}$} & $*(10)$ & $*(4)$ & $*(9)$ & $*(4)$ & $*(12)$ & $*(4)$ & $*(14)$ \\
\hline & 130,59 & 359 & 300 & 359 & 270,89 & 359 & $175,130,64$ \\
\hline \multirow{2}{*}{$\begin{array}{l}\text { Black pomfret } \\
\text { (Parastromateus niger) }\end{array}$} & $*(10)$ & $*(4)$ & $*(11)$ & $*(4)$ & $*(13)$ & $*(4)$ & $*(15)$ \\
\hline & 130,59 & 359 & 200,120 & 359 & $149,105,105$ & 359 & $170,120,79$ \\
\hline
\end{tabular}

\begin{tabular}{|c|c|c|c|c|c|c|c|}
\hline \multirow[t]{2}{*}{ Types of samples } & \multicolumn{7}{|c|}{ Size of DNA Band (bp) } \\
\hline & $A l u \mathrm{I}$ & BsaJI & HaeIII & Hind III & HinfI & $M b o \mathrm{I}$ & MboII \\
\hline $\begin{array}{l}\text { Anchovy } \\
\text { (Stolephorus commersonii) }\end{array}$ & - & - & - & - & - & - & - \\
\hline \multirow{2}{*}{$\begin{array}{l}\text { Mabong } \\
\text { (Rastrelliger kanagurta) }\end{array}$} & $*(10)$ & $*(4)$ & $*(16)$ & $*(4)$ & $*(17)$ & $*(18)$ & $*(19)$ \\
\hline & 130,59 & 359 & 239,120 & 359 & 200,100 & 250,109 & 200,90 \\
\hline \multirow{2}{*}{$\begin{array}{l}\text { Red snapper } \\
\text { (Lutjanus erythropterus) }\end{array}$} & $*(5)$ & & $*(11)$ & $*(4)$ & $*(22)$ & $*(21)$ & $*(20)$ \\
\hline & $170,130,59$ & - & 200,120 & 359 & 220 & 179,180 & 170,130 \\
\hline \multirow{2}{*}{$\begin{array}{l}\text { Herring } \\
\text { (Chirocentrus dorab) }\end{array}$} & $*(10)$ & $*(23)$ & $*(4)$ & $*(4)$ & $*(24)$ & $*(9)$ & $*(15)$ \\
\hline & 130,59 & 249,110 & 359 & 359 & $149,110,100$ & 300 & $170,120,79$ \\
\hline \multirow{2}{*}{$\begin{array}{l}\text { Ray fish } \\
\text { (Himantura gerrardii) }\end{array}$} & $*(10)$ & $*(6)$ & $*(11)$ & $*(4)$ & $*(26)$ & $*(4)$ & $*(30)$ \\
\hline & 130,59 & 225,134 & 200,120 & 359 & 170,120 & 359 & 160,110 \\
\hline \multirow{2}{*}{$\begin{array}{l}\text { Sardine } \\
\text { (Decapterus macrosoma) }\end{array}$} & $*(10)$ & $*(4)$ & $*(16)$ & $*(4)$ & $*(8)$ & $*(4)$ & $*(29)$ \\
\hline & 130,59 & 359 & 239,120 & 359 & 200,159 & 359 & 160,120 \\
\hline \multirow{2}{*}{$\begin{array}{l}\text { Mackerel } \\
\text { (Euthynnus affinis) }\end{array}$} & $*(10)$ & $*(4)$ & $*(11)$ & $*(4)$ & $*(27)$ & $*(4)$ & $*(31)$ \\
\hline & 130,59 & 359 & 200,120 & 359 & 259,100 & 359 & 280,79 \\
\hline \multirow{2}{*}{$\begin{array}{l}\text { Tuna } \\
\text { (Thunnus tuna) }\end{array}$} & $*(5)$ & $*(32)$ & $*(25)$ & $*(4)$ & $*(28)$ & $*(4)$ & $*(30)$ \\
\hline & $170,130,59$ & 210 & 150,100 & 359 & 200 & 359 & 160,110 \\
\hline
\end{tabular}

*(Profile number based on digestion pattern)

of fish species were compared to the restriction pattern of the pork amplicon.

Digestion of AluI towards amplicons of 11 fish samples has produced two digestion patterns. The first pattern resulted in three DNA fragments after digestion; $170 \mathrm{bp}, 130$ bp and 59 bp for catfish, shark catfish, red snapper and tuna. While the second pattern only two fragments produced; 130 bp and $59 \mathrm{bp}$ for perch, black pomfret, mabong, herring, ray fish, sardine and mackerel. The use of restriction enzyme $B s a \mathrm{JI}$ produced five digestion patterns towards the fish sample amplicons. A 225 bp and a 134 bp fragments were produced from amplicon of catfish and rayfish while, no digestion was observed towards amplicon of shark catfish, perch, black pomfret, mabong, sardine and mackerel. None of DNA fragments were observed for red snapper amplicon. Digestion of herring gives two fragments of $249 \mathrm{bp}$ and $110 \mathrm{bp}$ while, only one fragment was observed from tuna amplicon after digestion by BsaJI.

The third restriction enzyme used was HaeIII with six digestion patterns observed. This enzyme did not digest 


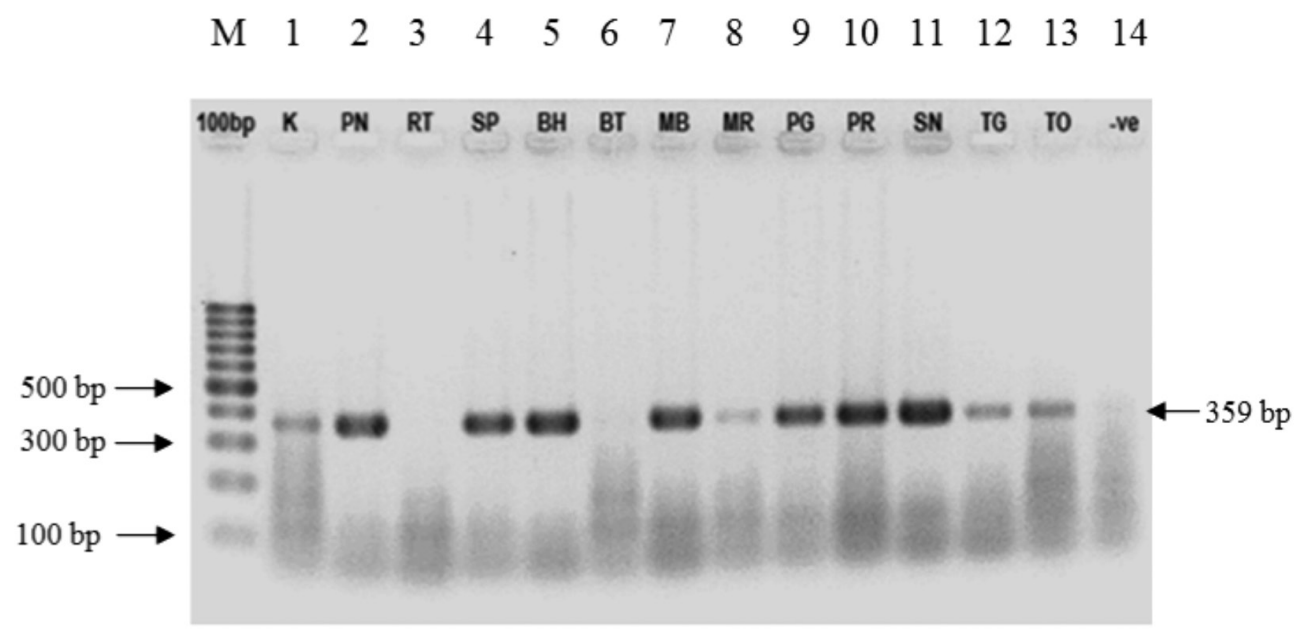

FIGURE 1. The PCR amplification product of oligonucleotide primers of CYTb1/CYTb2 for 14 species of raw fish. Lane M: 100 bp DNA ladder; 1: Catfish (Clarias gariepinus); 2: Shark catfish (Pangasius larnaudii); 3: Tilapia (Oreochromis mossambicus);

4: Perch (Lates calcarifer); 5: Black pomfret (Parastromateus niger); 6: Anchovy (Stolephorus commersonii);

7: Mabong (Rastrelliger kanagurta); 8: Red snapper (Lutjanus erythropterus); 9: Herring (Chirocentrus dorab);

10: Ray fish (Himantura gerrardii); 11: Sardine (Decapterus macrosoma); 12: Mackerel (Euthynnus affinis);

13: Tuna (Thunnus tuna); 14: Negative control (Nuclease-free water)

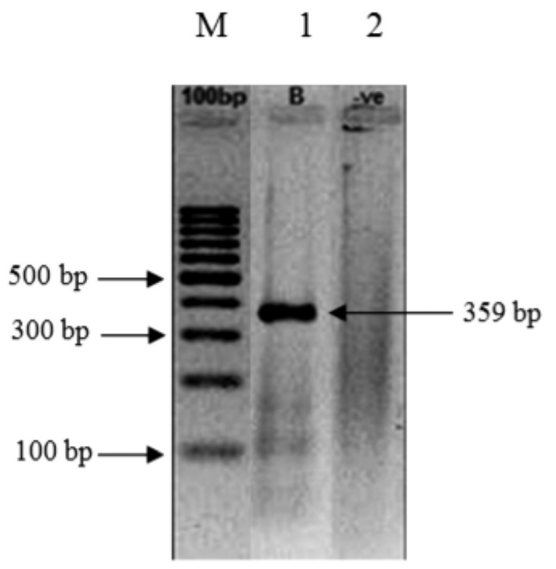

FIGURE 2. The PCR amplification product of oligonucleotide primers of CYTb1/CYTb2 for Sus scrofa domestica. Lane M: 100 bp DNA Ladder; Lane 1: Sus scrofa domestica; 2: Negative control (Nuclease-free water)

amplicon of shark catfish and herring. It digested catfish amplicon into two fragments of $229 \mathrm{bp}$ and $130 \mathrm{bp}$ while, only one fragment of $300 \mathrm{bp}$ was observed after digestion of perch amplicon. On the other hand, digestion by HaeIII restriction enzyme towards amplicon of black pomfret, red snapper, ray fish and mackerel has produced two fragments of $200 \mathrm{bp}$ and $120 \mathrm{bp}$. Mabong and sardine amplicon were also digested into two fragments but of different sizes which were $239 \mathrm{bp}$ and $120 \mathrm{bp}$. Tuna amplicon were digested into two other fragments of 150 and 100 by HaeIII. All DNA amplicon bands showed no digestion by restriction enzyme HindIII.

Nine digestion patterns were observed after amplicon digestion by HinfI. This enzyme produced the same digestion patterns toward catfish, shark catfish and sardine with 200 bp and 159 bp DNA fragments. Perch amplicon was digested into $270 \mathrm{bp}$ and $89 \mathrm{bp}$ fragments while black pomfret amplicon was also digested into $149 \mathrm{bp}$ and two fragments of $105 \mathrm{bp}$. Mabong, ray fish and mackerel amplicon were digested into two fragments which are 200 bp and 100 bp, 170 bp and 120 bp and 259 bp and 100 bp fragments. For red snapper and tuna, only one fragment of $220 \mathrm{bp}$ and $200 \mathrm{bp}$ was detected after digestion by HinfI, respectively. Meanwhile, herring amplicon was digested into three fragments of $149 \mathrm{bp}, 110 \mathrm{bp}$ and $100 \mathrm{bp}$.

The sixth enzyme used in this study was restriction enzyme $M b o I$. There were four digestion patterns identified after its enzymatic digestion towards PCR products. No digestion by $\mathrm{MboI}$ was detected towards catfish, perch, black pomfret, ray fish, sardine and mackerel amplicons. Digestion towards shark catfish and herring amplicon produced only one fragment of $300 \mathrm{bp}$. MboI digested amplicon of mabong into $250 \mathrm{bp}$ and $109 \mathrm{bp}$ while, amplicon of red snapper were digested into $179 \mathrm{bp}$ and $180 \mathrm{bp}$.

The last endonuclease used in the study was MboII. There were nine digestion patterns produced after digestion of sample amplicons by MboII. Two fragments of 200 bp and 159 bp were produced after digestion of catfish amplicons by MboII but this enzyme did not digest shark catfish amplicon. Meanwhile, three fragments with different sizes were identified after digestion of perch, black pomfret and herring amplicons. Perch amplicon was digested into 175 bp, 130 bp and 64 bp fragments. Amplicon of black pomfret and herring were digested into the same fragments of $170 \mathrm{bp}, 120 \mathrm{bp}$ and $79 \mathrm{bp}$. The other fish sample amplicons were digested into two fragments of different sizes. Amplicon of mabong was digested into 200 bp and $90 \mathrm{bp}$ fragments while red snapper was digested into $170 \mathrm{bp}$ and $130 \mathrm{bp}$ fragments. Ray fish and tuna amplicon 
were digested into same fragments of $160 \mathrm{bp}$ and $110 \mathrm{bp}$. Amplicon of sardine was digested into $160 \mathrm{bp}$ and $120 \mathrm{bp}$ fragments while, digestion of mackerel amplicon by MboII produced two fragments of $280 \mathrm{bp}$ and $79 \mathrm{bp}$ in molecular weight.

Comparison of fish PCR product digestion patterns to pork PCR product digestion pattern was shown in Figure 3. After digestion with all enzymes, amplicon restriction of $A l u \mathrm{I}$ and $\mathrm{MboI}$ produced the same two DNA fragments of 115 and 244 bp molecular sizes from the pork amplicon. $B s a \mathrm{JI}$ also produced two DNA fragments but with different molecular sizes which were 131 and 228 bp. Enzymatic digestion process towards $c y t \mathrm{~b}$ amplicon of pork using HaeIII endonuclease produced three DNA fragments with molecular weight of $125 \mathrm{bp}$ and $134 \mathrm{bp}$. Meanwhile, the use of HinfI, HindIII and MboII showed no restriction reaction.
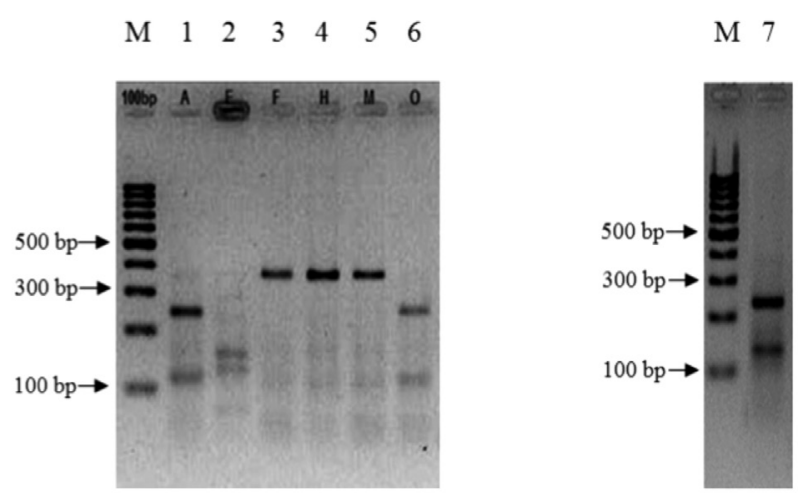

FIGURE 3. Pork (Sus scrofa domestica) DNA bands after digestion using seven restriction enzymes (RE). Lane M: 100 bp DNA Ladder; 1: RE AluI; 2: RE HaeIII; 3: RE Hinfl; 4: RE HindIII; 5: RE MboII; 6: RE MboI; 7: RE BsaJI

\section{DISCUSSION AND CONCLUSION}

In this study, universal cyt $\mathrm{b}$ primer CYTb1/CYTb2 (Kocher et al. 1989) was used to amplify cyt b mitochondrial DNA from all 13 fish species and pork due to mitochondria DNA endurance to degradation at high temperature and extreme processing condition. Partis et al. (2000) also reported that PCR analysis using $c y t \mathrm{~b}$ as primer got higher sensitivity compared to nuclear DNA, due to the number of $c y t \mathrm{~b}$ locus copies exist in each cell. Discriminatory ability of the selected primer was also crucial for identification purposes (Sahilah et al. 2010). This primer targeted the $359 \mathrm{bp}$ sequence of $c y t$ b to be amplified. The size of amplification products obtained for each sample was 359 bp except for tilapia (Oreochromis mossambicus) and anchovy (Stolephorus commersonii) samples. The reason no amplicon was detected for both fish samples were probably due to no specific site on the genomic DNA for the annealing of the $c y t \mathrm{~b}$ primer. No specific site on both fishes were cause by sequence variation of $c y t \mathrm{~b}$ region binding site in different fish species as reported by Ivanova et al. (2007). In their report, a mixture of several complicated primers usually is required to ensure the annealing process occurs.

In PCR-RFLP, the unique sizes of fragments produced were due to the variation of restriction sites detected by the endonucleases on the gene sequences by species. Every species may have their own specific sequences even for the same region. Molecular weights for each fragment is differ from each other, allowed them to be compared between species. Each restriction endonuclease has the ability to identify a specific site based on DNA base recognition (Perbal 1988). All PCR products showed no digestion towards $c y t$ b amplicon by HindIII may be due to the absence of the targeted nucleotide sequence. This observation was similar as reported by Murugaiah et al. (2009) which HindIII could not be used to differentiate between pork, beef, buffalo, chicken, mutton, puyuh and rabbit samples. Thus, HindIII is not advisable to be used in meat differentiation in future.

In the present study, the restriction of fish DNAgenome showed variation of lengths produced after the enzymatic digestion, since different species consist of different genome sequences as in many genome sequencing results (Salih et al. 2017; Yoon et al. 2017). The results indicated in Table 1 supports this statement, both in genomic fishes and pork DNA patterns. These findings were in agreement in the previous studies by Ong et al. (2007) and Sahilah et al. (2012) who reported the ability of $A l u \mathrm{I}$ and $B s a \mathrm{JI}$ to digest $c y t$ b DNA amplicon of pork as well as fish in this study. In this study, analysis of the endonuclease restriction patterns from fish and pork samples tabulated in Table 1 indicates the differentiation of fishes and pork DNA genome with different fragments size produced. It showed a specific fragment patterns for both DNA genome. Thus, PCR-RFLP analysis is useful for future pork DNA detection in fish products.

\section{ACKNOWLEDGEMENTS}

This study was supported by the Fundamental Research Grant Scheme (UKM-ST-06-FRGS0010-2008), Ministry of Higher Education (MOHE), Malaysia.

\section{REFERENCES}

Ivanova, N.V., Zemlak, T.S., Hanner, R.H. \& Hebert, P.D.N. 2007. Universal primer cocktails for fish DNA barcoding. Molecular Ecology Notes 7(4): 544-548.

Kocher, T.D., Thomas, W.K., Meyer, A., Edwards, S.V., Pabo, S., Villablanca, F.X. \& Wilson, A.C. 1989. Dynamics of mitochondrial DNA evolution in mammals: Amplification and sequencing with conserved primers. Procedure National Academy of Science USA 86(16): 6196-6200.

Koh, M.C., Lim, C.H., Chua, S.B., Chew, S.T. \& Phang, S.T.W. 1998. Random amplified polymorphic DNA (RAPD) fingerprints for the identification of red meat animal species. Meat Science 48(3/4): 275-285.

Matsunaga, T., Chikuni, K., Tanabeb, R., Muroyab, S., Shibata, K., Yamadaa, J. \& Shinmuraa, Y. 2001. A quick and simple method for the identification of meat species and meat products by PCR assay. Meat Science 51: 143-148. 
Monin, G. 1998. Recent methods for predicting quality of whole meat. Meat Science 49(1): S231-S243.

Murugaiah, C., Zainon, M.N., Maimunah, M., Lesley, M.B., Jinap, S. \& Son, R. 2009. Meat species identification and Halal authentication analysis using mitochondrial DNA. Meat Science 3: 57-61.

Ong, S.B., Zuraini, M.I., Jurin, W.G., Cheah, Y.K., Tunung, R., Chai, L.C., Haryani, Y., Ghazali, F.M. \& Son, R. 2007. Reaction-restriction fragment length polymorphism in species differentiation of meat from animal origin. ASEAN Food Journal 14(1): 51-59.

Partis, L., Croan, D., Guo, Z., Clark, R., Coldham, T. \& Murby, J. 2000. Evaluation of a DNA fingerprinting method for determining the species origin of meats. Meat Science 54: 369-376

Perbal, B. 1988. A Practical Guide to Molecular Cloning. 2nd ed. New York: John Wiley and Sons. Inc.

Sahilah, A.M., Nor' Aishah, H., Noraida, I. \& Ahmad Azuhairi, A. 2010. Detection of Shiga toxin 1 and 2 (stx1 and stx2) genes in Escherichia coli O157:H7 isolated from retail beef in Malaysia by multiplex polymerase chain reaction (PCR). Sains Malaysiana 39(1): 57-63.

Sahilah, A.M., Wan Sakeenah, W.N., Safiyyah, S., Norhayati, Y., Norrakiah, A.S., Aminah, A., Abdul Salam, B. \& Maaruf, A.G. 2012. Comparison between pork and wild boar meat (Sus scrofa) by polymerase chain reaction-restriction fragment length polymorphism (PCR-RFLP). Sains Malaysiana 41(2): 199-204.
Salih, R.H.M., Majesky, L., Shwarzacher, T., Gornall, R. \& Harrison, P.H. 2017. Complete chloroplast genomes from apomictic Taraxacum (Asteraceae): Identity and variation between three microspecies. PLOS ONE 12(2): e0168008.

Yoon, S.H., Ha, S.M., Kwon, S., Lim, J., Kim, Y., Seo, H. \& Chun, J. 2017. Introducing EzBioCloud: A taxonomically united database of $16 \mathrm{~S}$ rRNA gene sequences and whole genome assemblies. International Journal of Systematic and Evolutionary Microbiology 67: 1613-1617.

School of Chemical Sciences and Food Technology Faculty of Science and Technology Universiti Kebangsaan Malaysia 43600 UKM Bangi, Selangor Darul Ehsan Malaysia

*Corresponding author; email: sahilah@ukm.edu.my

Received: 14 September 2017

Accepted: 23 February 2018 